\title{
Enterovirus and herpesviridae family as etiologic agents of lymphomonocytary meningitis, Southern Brazil
}

\author{
Luine Rosele Renaud Vidal', Sérgio Monteiro de Almeida², \\ lara José de Messias-Reason³ ${ }^{3}$ Meri Bordignon Nogueira4, \\ Maria do Carmo Debur ${ }^{5}$, Luís Felipe Cavalli Pessa ${ }^{6}$, \\ Luciane Aparecida Pereira6, Indianara Rotta ${ }^{7}$, \\ Gislene Reche de Almeida Takahashi ${ }^{8}$, Clyete Santos da Silveira ${ }^{8}$, \\ Josianne Maria Reimann Araújo ${ }^{9}$, Sonia Mara Raboni ${ }^{10}$
}

\begin{abstract}
Viral meningitis is a common infectious disease of the central nervous system (CNS) that occurs worldwide. The aim of this study was to identify the etiologic agent of lymphomonocytary meningitis in Curitiba, PR, Brazil. During the period of July 2005 to December 2006, 460 cerebrospinal fluid (CSF) samples with lymphomonocytary meningitis were analyzed by PCR methodologies. Fifty nine (12.8\%) samples were positive. Enteroviruses was present in 49 (83\%) samples and herpes virus family in $10(17 \%)$, of these $6(10 \%)$ herpes simplex virus, 1 (2\%) Epstein Barr virus, 2 (3\%) human herpes virus type 6 and $1(2 \%)$ mixed infection of enterovirus and Epstein Barr virus. As conclusion enterovirus was the most frequent virus, with circulation during summer and was observed with higher frequency between 4 to 17 years of age. PCR methodology is an important method for rapid detection of RNA enterovirus and DNA herpesvirus in CSF.

Key words: aseptic meningitis, lymphocytic meningitis, lymphomonocytary meningitis, cerebrospinal fluid, central nervous system, enterovirus, herpesvirus.
\end{abstract}

Enterovirus e família herpesviridae como agentes etiológicos de meningites linfomonocitárias, no sul do Brasil

\section{RESUMO}

A meningite viral é uma síndrome infecciosa comum do sistema nervoso central (SNC), que ocorre no mundo inteiro. O objetivo deste estudo foi identificar o agente etiológico de meningite linfomonocitária em Curitiba, PR, Brasil. Durante o período de julho de 2005 a dezembro de 2006, 460 amostras com meningite linfomonocitária foram analisadas por metodologias de PCR. Cinquenta e nove (12,8\%) amostras foram positivas. Enterovirus estava presente em 49 (83\%) amostras e herpes vírus em 10 (17\%), destas 6 (10\%) HSV, 1 (2\%) EBV, 2 (3\%) HHV- 6 e 1 (2\%) infecção mista de enterovírus e EBV. Conclui-se que

\section{Correspondence}

Sérgio Monteiro de Almeida Hospital de Clínicas (UFPR)

Setor Análises Clínicas

Laboratório de Virologia Rua Padre Camargo 280 80060-240 Curitiba PR - Brasil E-mail: sergio.ma@pop.com.br

\section{Support}

SETI - Secretaria de Ciência e

Tecnologia do Estado do Paraná

Received 28 September 2010 Received in final form 4 January 2011 Accepted 13 January 2011 o enterovirus foi o vírus mais frequente, com a circulação durante o verão. Houve maior número de amostras positivas entre 4 a 17 anos. A metodologia de PCR é um importante método para a detecção rápida de RNA de enterovirus e DNA do herpesvirus no LCR. Palavras-chave: meningite asséptica, meningite linfocítica, meningite linfomonocitária, líquido cefalorraquidiano, sistema nervoso central, enterovirus, herpesvirus.

1Pharmacist, MD Student of Postgraduate Program of Pharmacy Science from Universidade Federal do Paraná (UFPR), Virology Laboratory, Hospital de Clínicas, Curitiba PR, Brazil; ${ }^{2}$ Medical Doctor, PhD, Virology Laboratory, Hospital de Clínicas, UFPR, Curitiba PR, Brazil. Pelé Pequeno Príncipe Research Institute, Curitiba PR, Brazil; ${ }^{3}$ Pharmacist PhD, Immunopathology Laboratory, Hospital de Clínicas, UFPR; ${ }^{P}$ Pharmacist PhD, Virology Laboratory, Hospital de Clínicas, UFPR; ${ }^{5}$ Pharmacist MS, Laboratório Central do Estado do Paraná, LACEN, Curitiba PR, Brazil; ${ }^{6}$ Biologist, Virology Laboratory, Hospital de Clínicas, Curitiba PR, Brazil; ${ }^{7}$ Pharmacist, Virology Laboratory, Hospital de Clínicas, Curitiba PR, Brazil; ${ }^{8}$ Technician, Virology Laboratory, Hospital de Clínicas, Curitiba PR, Brazil; ${ }^{9}$ Phisician, Secretaria Municipal de Sáude do Estado do Paraná; ${ }^{10}$ Medical Doctor, PhD, Virology Laboratory, Hospital de Clínicas, UFPR. 
Viral meningitis is a common infectious disease of the central nervous system (CNS) that occurs worldwide, especially during the summer. Almost $90 \%$ of cases are caused by enterovirus such as, coxsackievirus and echovirus which contain several serotypes ${ }^{1}$. They are easily transmitted by direct contact with respiratory secretions that can cause epidemic outbreaks with high financial impact and morbidity rates. These viruses are typically geographically confined and some serotypes may arise in endemic regions, with gradual changes in the predominant serotypes present year to year ${ }^{1,2}$. Enterovirus meningitis is the most common agent identified in most viral meningitis cases, followed by herpesviridae family viruses $^{3}$. Viral meningitis is responsible for approximately $50 \%$ of inpatients with meningitis in the city of Curitiba, Southern Brazil ${ }^{4}$.

The number of notified cases of meningitis from all etiologies (bacterial, viral and not otherwise specified) in Curitiba from 1995 to 2003 was from 612 to 896. It is estimated that $40 \%$ of the meningitis cases were caused by viruses and the coefficient for the incidence of viral meningitis was around 29 cases/100,000 inhabitants ${ }^{4}$. There is little information on the etiology of viral meningitis in Brazil especially in the Southern region. In this study we identified the etiologic agent of viral meningitis that occurred in Curitiba, the capital of Paraná State, in Southern Brazil, in the July 2005 to December 2006 period using biology molecular approaches.

\section{METHOD}

The city of Curitiba is located in the southern Brazil at an altitude of $934.6 \mathrm{~m}$, and has subtropical climate. It is the seventh largest city in Brazil with a population of around 1,850.000 inhabitants and a population density of $4,202.83 \mathrm{hab} / \mathrm{km}$. In the period of July 2005 to December 2006 a total of 671 cerebrospinal fluid (CSF) samples were collected from patients with clinical suspicion of lymphomonocytary meningitis seen at three different reference hospitals in Curitiba (Hospital Universitário Evangélico, Hospital Pequeno Príncipe and Hospital de Clínicas-UFPR). CSF samples were stored in a RNA/ DNAse free and sterile tube and sent to the virology laboratory for less than 24 hours, on ice. There was a label on each sample containing epidemiological and clinical data the samples were stored at $-70^{\circ} \mathrm{C}$ until molecular analysis.

Inclusion criteria - CSF samples were included in the study based on the clinical criteria of meningitis: acute onset ( $<3$ weeks), presence of fever $\left(>38^{\circ} \mathrm{C}\right)$, meningo-radicular signs and headache. CSF biochemical and cytological pattern of viral meningitis are: WBCs $\geq 5$ cells $/ \mathrm{mm}^{3}$ with predominance of lymphocytes, CSF glucose normal ( $>45 \mathrm{mg} / \mathrm{dL})$, CSF lactate $<3.5 \mathrm{mmol} / \mathrm{L}^{5}$.
Exclusion criteria - [1] Clinical diagnosis of encephalitis, defined as acute onset ( $<3$ weeks), the presence of fever $\left(>38^{\circ} \mathrm{C}\right)$ and signs or symptoms that suggested brain parenchyma involvement (consciousness and/or personality alterations, seizures or focal neurological signs $)^{6}$; [2] Samples with CSF biochemical and cytological characteristics of bacterial meningitis: WBCs $>5$ cells $/ \mathrm{mm}^{3}$ with predominance of neutrophils, low CSF glucose normal $(<45 \mathrm{mg} / \mathrm{dL})$, CSF lactate $>3.5 \mathrm{mmol} / \mathrm{L}$; [3] Samples improperly stored, non-refrigerated samples or sent improperly to the virology section; [4] Identification in CSF of an etiologic agent other than virus.

CSF total protein was quantified by the sulphosalicylic acid turbidimetric method and CSF glucose by the enzymatic method. CSF total cell count (WBCs) was assessed using a Fuchs Rosenthal chamber. For differential cell count CSF samples were concentrated in a cytospin and the slides stained by the May Grünwald-Giemsa technique.

The study was approved by the Ethical and Research Committee on Humans Beings from the Hospital de Clínicas, UFPR.

\section{Extraction of viral RNA/DNA}

The extraction of viral RNA or DNA was followed by a previously described protocol ${ }^{7}$. Briefly, $200 \mu \mathrm{L}$ of lysis buffer (Guanidine Isothyocianate (GuSCN), Invitrogen (USA) 4 M, 0.5\% of N-Lauroylsarcosine salt solution, Fluka (USA), $1 \mathrm{mM}$ dithiotreitol (DTT), Invitrogen (USA), 25 mM sodium citrate, Sigma (USA), 20 $\mu \mathrm{g} /$ tube of glycogen, Sigma (USA), 100 copies of plasmid with pseudo rabies virus (PRV), used as internal control were added to $50 \mu \mathrm{L}$ of CSF. After, vortexed tube was incubated room temperature for 10 minutes. $250 \mu \mathrm{L}$ of isopropyl alcohol $\left(-20^{\circ} \mathrm{C}\right)$ was added, vortexed and centrifuged for 10 minutes, $17,000 \mathrm{rpm}$ at $4^{\circ} \mathrm{C}$. Pellet was washed with $500 \mu \mathrm{L}$ of ethanol 70 , centrifuged as described. Supernatant was discarded and the open tube incubated at $56^{\circ} \mathrm{C}$ for 10 minutes. The dried pellet was resuspended in ultrapure water and stored at $-70^{\circ} \mathrm{C}$.

\section{Reverse transcription}

Viral RNA was transcribed to obtain cDNA as described elsewhere ${ }^{8}$. The master mix was prepared in a volume of $17.5 \mu \mathrm{L} /$ tube. The mix contained dideoxynucleotides triphosphates $2.5 \mathrm{mM}$ (dNTPs), $5 \mathrm{X}$ buffer (Invitrogen, USA), dithiothreitol (DTT) $0.1 \mathrm{M}$ (invitrogen, USA), $0.25 \mu \mathrm{L}$ of RNAse Out (Invitrogen, USA) and transcriptase enzyme Superscript II (Invitrogen, USA) 0.25 $\mu \mathrm{L} .0 .5 \mu \mathrm{L}$ of the enterovirus antisense primer was added to $10 \mu \mathrm{L}$ of the extracted product. After 2 minutes at $94^{\circ} \mathrm{C}$ ice cooling, $17.5 \mu \mathrm{L}$ of the mix was added to the tube, which was stored at $45^{\circ} \mathrm{C}$ for 1 hour. 


\section{Amplification - PCR}

Enterovirus - PCR for enterovirus was based on the amplification of the 5'-UTR region of the gene, which is a highly conserved region in most enterovirus serotypes according to Casas et al. ${ }^{9}$. For the first PCR the primer sequences were: EV1- Reverse 5'GAAACACGGACACCAAAGTAGTCG3' and EV1 - Forward 5'CGGTACCTTTGTRCGCCTGTTTTA3'. The amplification consisted of two rounds. For the first PCR the master mix contained $10 \mathrm{mM}$ Tris-HCL (pH 8.8), $3.5 \mathrm{mM}$ $\mathrm{MgCl}_{2}, 2.5 \mathrm{mM} \mathrm{KCl}, 1.5 \mathrm{U}$ of Taq polymerase and $0.5 \mu \mathrm{L}$ of each external primer in a concentration of $10 \mathrm{pmol}$, the final volume was adjusted with ultra pure water to $22.5 \mu \mathrm{L}$ and $2.5 \mu \mathrm{L}$ of cDNA. The amplification was performed with an Eppendorf thermocycler in one cycle of $94^{\circ} \mathrm{C}$ for 2 minutes, followed by 40 cycles: $94^{\circ} \mathrm{C}$ for 30 seconds, $48^{\circ} \mathrm{C}$ for 30 seconds and $72^{\circ} \mathrm{C}$ for 2 minutes, after extension on $72^{\circ} \mathrm{C}$ for 10 minutes. For the second PCR the primer sequences were as follows: EV2 - Reverse 5'GGATTAGCCGCATTCAGGG3'; EV2 - Forward 5'CAAGCACTTCTGTTTCCCCG3'. Master mix for the second PCR was described above and the volume of Taq polymerase was $0.25 \mu \mathrm{L} .0 .5 \mu \mathrm{L}$ from the first amplification product and $24.5 \mu \mathrm{L}$ from the mix were used. The second amplification was performed with an Eppendorf thermocycler in one cycle of $94^{\circ} \mathrm{C}$ for $2 \mathrm{~min}$ utes, followed by 30 cycles of $94^{\circ} \mathrm{C}$ for 30 seconds, $52^{\circ} \mathrm{C}$ for 30 seconds, $72^{\circ} \mathrm{C}$ for 1 minute, after an extension on $72^{\circ} \mathrm{C}$ for 10 minutes. Amplification products were analyzed in $1 \%$ agarosis gel. The expected product for enterovirus was of 306-316 pb and for the internal control, PRV $147 \mathrm{pb}$.

Herpesviridae family - The herpesviruses were identified by the methodology described by Johnson et al. ${ }^{10}$, which was standardized to detect eight species of human herpesviruses. Primers were designed for a well conserved region of the DNA polymerase gene. The first pair of primers (PAN1) was used to amplify herpes simplex virus type 1 (HSV-1), herpes simplex virus type 2 (HSV-2), Epstein Barr virus (EBV), Cytomegalovirus (CMV), and human herpes virus type 8 (HHV-8) and had the following sequences: HSV P1 - 5'-GTGGTGGACTTTGCCAGCCTGTACCC-3' and HSV-P2 5'-TAAACATGGAGTCCGTGTCGCCGTAGATGA-3. The primer pair 2 (PAN2) was used to amplify varicella zoster virus (VZV), human herpes virus type 6 (HHV-6) (variant A or B), and HHV-7 presented the following sequence VZV-P1 - 5'-TCGTGTTTGATTTTCAAAGTTTATATCC-3' and VZV-P2 5'-ATAAACACACAATCCGTATCACCATAAATAACCT-3'. Polymerase Chain Reaction was performed in a total volume of $25 \mu \mathrm{L}$. The mix contained $2.5 \mu \mathrm{L}$ of $10 \mathrm{X}$ buffer (Invitrogen, USA), $0.75 \mu \mathrm{L}$ magnesium chloride $\left(\mathrm{MgCl}_{2}\right) 50 \mathrm{mM}$ (Invit- rogen), $8 \mu \mathrm{L}$ dNTPs $1.25 \mathrm{mM}$ (Invitrogen), $1.25 \mu \mathrm{L}$ of dimethyl sulfoxide (DMSO) (Merck), $1.75 \mu \mathrm{L}$ of each primer in a concentration of $37.5 \mathrm{pmol}, 0.35 \mu \mathrm{L}$ de Taq polymerase (Invitrogen), ultra pure water and $2,5 \mu \mathrm{L}$ from DNA. The amplification was performed with an Eppendorf cycler. For the first pair of primers the cycle was as follows: 1 cycle $95^{\circ} \mathrm{C}$ for 12 minutes, 3 cycles of $95^{\circ} \mathrm{C}$ for 1 minute, $60^{\circ} \mathrm{C}$ for 1 minute, $72^{\circ} \mathrm{C}$ for 1 minute, 37 cycles of $95^{\circ} \mathrm{C}$ for 1 minute, $55^{\circ} \mathrm{C}$ for 45 seconds, $72^{\circ} \mathrm{C}$ for 1 minute, 1 cycle $72^{\circ} \mathrm{C}$ for 3 minutes. For the second pair of primers the cycles were: 1 cycle $95^{\circ} \mathrm{C}$ for $12 \mathrm{~min}$ utes, 40 cycles of $95^{\circ} \mathrm{C}$ for 1 minute, $47^{\circ} \mathrm{C}$ for 1 minute, $72^{\circ} \mathrm{C}$ for 1 minute, 1 cycle $72^{\circ} \mathrm{C}$ for 3 minutes. The amplification products were analyzed by electrophoresis using $1 \%$ agarosis gel. The expected product for PAN 1 was 532 bp and for PAN $2536 \mathrm{bp}$. For each reaction positive and negative samples as well as water were used as controls.

\section{Restriction enzyme digestion}

Samples with products of approximately 532 or 536 bp were selected for enzyme digestion. Each reaction mixture in which amplicons were detected was subjected to digestion with the restriction enzymes BamHI and $B s t$ UI (New England Biolabs, USA). The digestion mixture consisted of $10 \mu \mathrm{L}$ of PCR mixture, $1.5 \mu \mathrm{L}$ of the appropriate enzyme buffer, $1 \mu \mathrm{L}$ of enzyme, and $2.5 \mu \mathrm{L}$ of double-distilled water for a total volume of $15 \mu \mathrm{L}$. The reaction mixtures were incubated for $1 \mathrm{~h}$ at $37^{\circ} \mathrm{C}(\mathrm{BamHI})$ or $60^{\circ} \mathrm{C}(B s t \mathrm{UI})^{10}$.

\section{Statistical analysis}

Variables were compared using Student T test, Chi Square and Mann Whitney tests, as appropriated. Results are shown as mean and standard deviation or frequencies and percentage. A p value $<0.05$ was considered significant.

\section{RESULTS}

During the July 2005 to December 2006 period a total 671 CSF samples were evaluated, with 460 samples (460 patients) fulfilling the inclusion criteria for the study. A total 59/460 (12.8\%) samples showed positive results for enterovirus $(\mathrm{n}=48)$, herpes simplex virus $(\mathrm{n}=6)$, Epstein Barr virus $(n=1)$, human herpes virus type $6(n=2)$ and a mixed infection with both enterovirus and Epstein Barr virus $(n=1)$. Enteroviruses represented $83 \%$ of positive samples herpes virus family $17 \%$. Samples of herpesvirus samples were digested by restriction enzymes and identified according to the pattern of the signals in the agarosis gel being 6 (10\%) for herpes simplex virus, 1 (2\%) for Epstein Barr virus and 2 (3\%) for human herpes virus type 6 and 1 (2\%) co infection of enterovirus and Epstein Barr virus (Fig 1). CMV, VZV, HHV-7, HHV-8 were not 
Table 1. Laboratorial findings of CSF positives and negatives samples based on cellular and biochemical features.

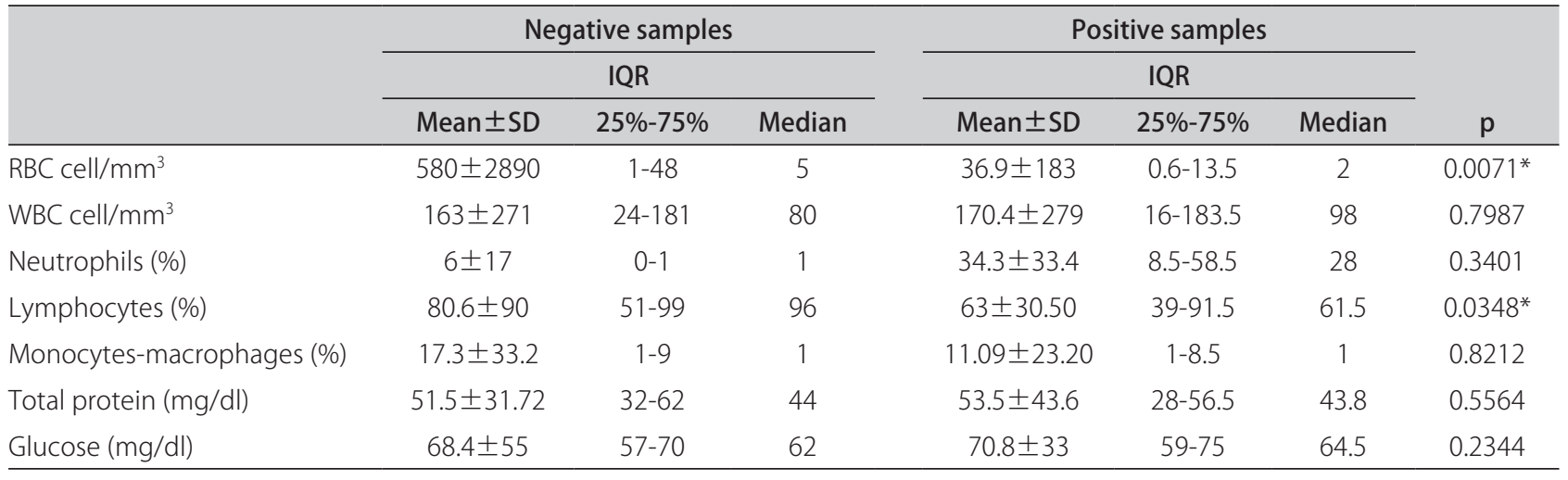

${ }^{*} \mathrm{p}<0.05$ Mann Whitney Test. RBC: red blood cells; WBC: white blood cells; IQR: interquartiles reference; SD: standard deviation.

found. All negative samples for the tested viruses were positive for the PRV internal control assay indicating efficient nucleic acid extraction.

Biochemical and cellular CSF characteristics of positive and negative samples are shown in Table 1. CSF samples with negative results had RBC mean of $580 \pm 2890$ cell $/ \mathrm{mm}^{3}$ compared to the positive samples where the mean was $36.9 \pm 183 \mathrm{cell} / \mathrm{mm}^{3}$ ( $\left.\mathrm{p}=0.0071\right)$.

There were higher numbers of positive samples during summer months with a median temperature of $21.5^{\circ} \mathrm{C}$ (Fig 2), mainly for enteroviruses. Herpesviruses were distributed along the year but its circulation was not observed during the winter months.

There were a high number of positive samples for the 4-6 age group (34\%) and 7-17 age group (31\%). The same distribution was observed for the cases with suspicion of acute lymphomonocytary meningitis with PCR negative results, being 234 (59\%) male and 161 (41\%) female patients $(\mathrm{p}=0.6677)$. The same pattern was observed for positive samples, 33 (57\%) male and 25 (43\%) female. The mean age of patients for positive enteroviruses was $6 \pm 5$ years old and for herpesviruses $11 \pm 14$ years old. Table
2 shows the age intervals for positive and negative samples. The percentage for positive and negative samples, was great for $4-17$ age group $(296 / 453)(p=0.0012)$. It is noteworthy, enterovirus positive samples $(48 / 59)$ the mean age was $6 \pm 5$ years and for herpesviruses $(10 / 58)$

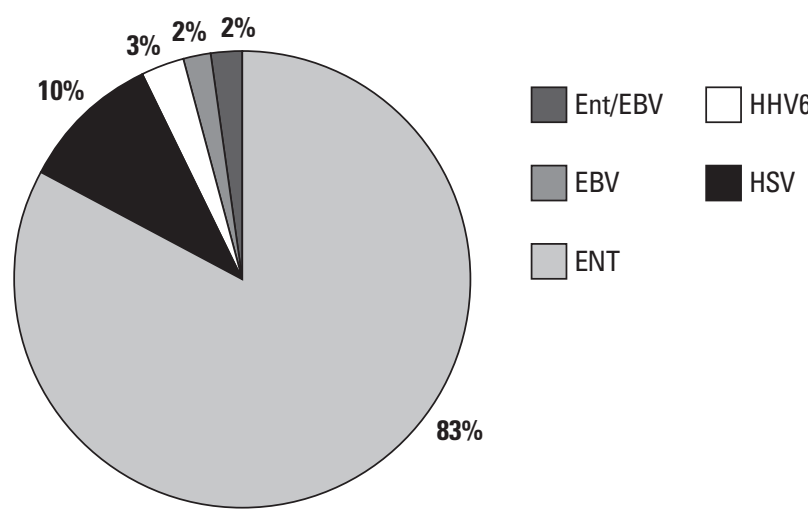

Fig 1. Percentage for positive samples in the period of the study for enterovirus (ENT), herpes simplex virus (HSV) human herpes virus type 6 (HHV6) Epstein Barr virus (EBV) and mixed infection enterovirus and Epstein Barr virus (ENT/EBV).

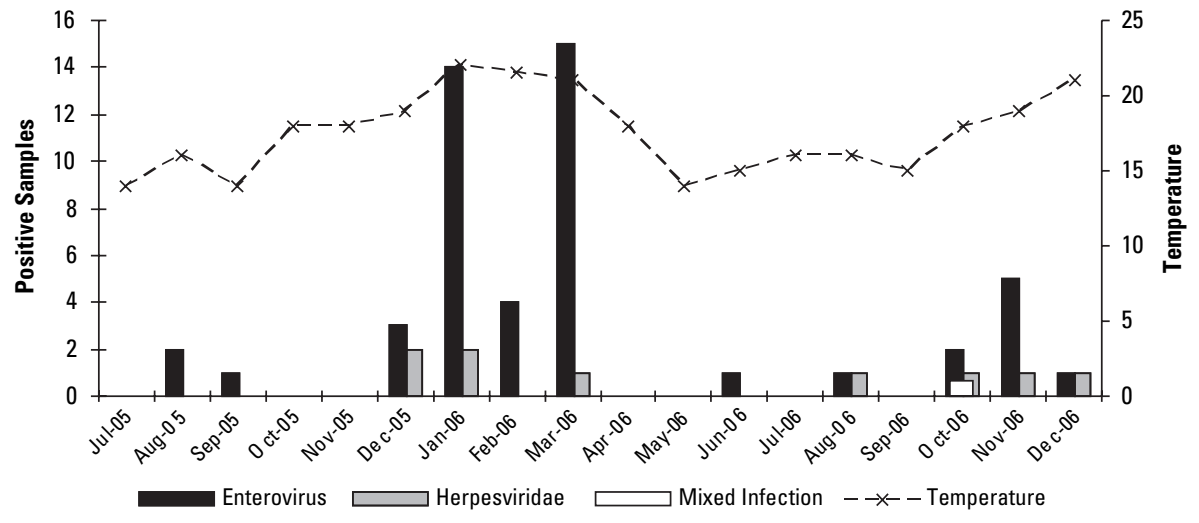

ENT: enterovirus; HSV: herpes simplex virus; EBV: Epstein Barr virus; HHV6: human herpes virus type 6; ENT/EBV: mixed infection; Temp: average temperature.
Fig 2. Montly distribution of positive samples and average temperature. 


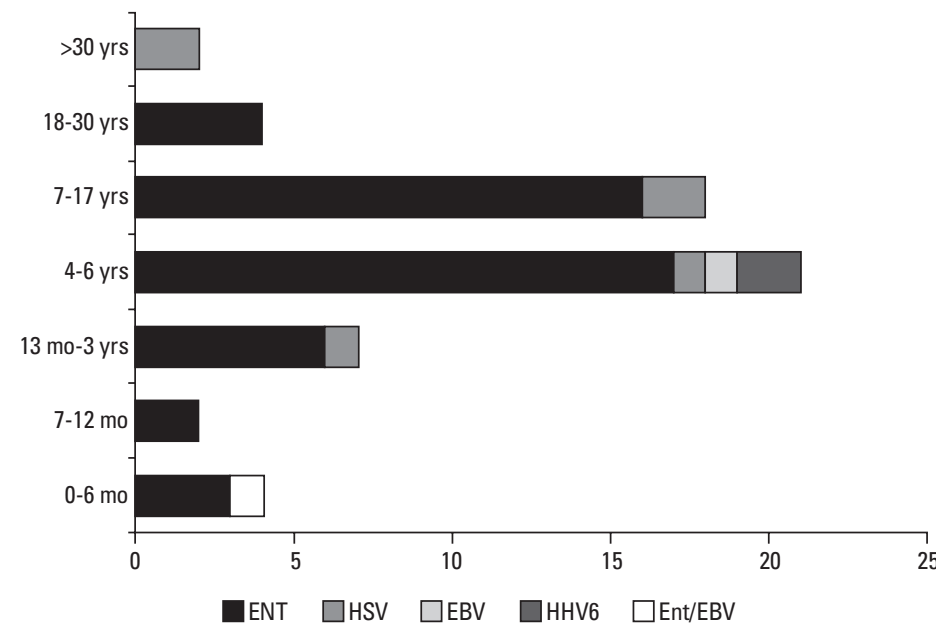

ENT: enterovirus; HSV: herpes simplex virus; EBV: Epstein Barr virus; HHV6: human herpes virus type 6; ENT/EBV: mixed infection.

Fig 3. Distribution of positive CSF samples by age.
Table 2. CSF negatives and positives samples from patients. epidemiological characteristics.

\begin{tabular}{lccc}
\hline & $\begin{array}{c}\text { Family } \\
(\mathbf{n}=48)\end{array}$ & $\begin{array}{c}\text { Herpesviridae } \\
(\mathbf{n}=10)\end{array}$ & $\begin{array}{c}\text { Negative } \\
(\mathbf{n}=395)\end{array}$ \\
\hline Gender & & & \\
M & $26(54 \%)$ & $7(70 \%)$ & $234(59 \%)$ \\
F & $22(46 \%)$ & $3(30 \%)$ & $161(41 \%)$ \\
Distribution by age & & \\
0-6 mo & $3(6.25 \%)$ & $0(10 \%)$ & $15(3.8 \%)$ \\
7-12 mo & $2(4.16 \%)$ & $2(20 \%)$ & $37(9.4 \%)$ \\
13 mo-3 yrs & $6(12.5 \%)$ & 0 & $67(17 \%)$ \\
$4-6$ yrs & $17(35.4 \%)$ & $3(30 \%)$ & $132(33.4 \%)$ \\
7-17 yrs & $16(33.3 \%)$ & $2(20 \%)$ & $131(33.1 \%)$ \\
$18-30$ yrs & $4(8.39 \%)$ & $1(10 \%)$ & $6(1.5 \%)$ \\
$>30$ yrs & 0 & $2(20 \%)$ & $7(1.8 \%)$ \\
\hline
\end{tabular}

Kruskal Wallis: $p=0.0012$. were $11 \pm 14$ years old $(\mathrm{p}=0.7645)$. The mean age for negative patients was $7 \pm 7.5$ years old. Fig 3 shows the distribution of positive samples according to age. Enterovirus was present in all ages under 30 years. However, positive samples were more prevalent in the ages of 4-17 age group (66.8\%). On the other hand, positivity for Herpesviridae family was lower with proportional distribution in all ages. The mixed infection with enterovirus and Epstein Barr virus was observed in a 3 month old child.

\section{DISCUSSION}

There is little information on viral infections of the CNS in Southern Brazil. The findings of the present study have contributed to a better understanding of the epidemiology of these viruses in this region. We showed here that enterovirus is the main etiologic agent of viral meningitis in Curitiba and probably in the south Brazil, which is in accordance with different reports for other geographic regions ${ }^{11,12}$. The circulation of the enterovirus occurred mainly in the summer and autumn similarly to that described for the northern hemisphere. In temperate climates the EVs appear markedly during summer/autumm seasonality. However, a high yearround incidence occurs in tropical and subtropical areas. It is believed that fecal-oral spread of these agents is facilitated, particularly among children, during periods of warm weather. In addition to direct person to person transmission, EVs may be recovered from houseflies, wastewater and sewage ${ }^{13}$. Our data is in agreement with those different authors who affirm the importance of establishing a diagnostic tool for patient management as well as carrying out epidemiological analysis to monitor the reappearance of new strains and epidemics by enteroviruses ${ }^{14,15}$. Santos et al. described the frequency of enterovirus meningitis analyzing CSF samples collected in 11 states in Brazil ${ }^{16}$. Enterovirus was detected in $15.8 \%$ of them with a predominance of Echovirus type 30 , and five meningitis outbreaks were identified during the study period from 1998 to 2003. The authors pointed out the importance of evaluating epidemiological features responsible for the frequency of viral meningitis and phylogenetic relationships between serotypes in Brazil $^{16}$. Mendonza et al. described virus involvement in SNC infections in Brazil ${ }^{17}$. This analysis was performed in 200 CSF samples and viral genome was detected in 23.34\%, which includes CMV (6\%), HSV1 (5\%), VZV and EBV $(0.5 \%)$ and enterovirus $(11.34 \%)^{17}$. Another study in northern Brazil found 13.2\% of positive CSF samples for enterovirus using cellular culture, immunofluorescence and neutralization test. The authors reported the importance of determining a national picture of viral meningitis in Brazil since it is still incomplete ${ }^{18}$. Despite the use of different methodologies, the proportion of positive samples was similar to that observed in this study. The incidence of the different viruses varies globally according to different populations, methodologies and objectives of the study. Enteroviruses detected by molecular biology RT-PCR or Real Time PCR or cellular culture analysis show an incidence varying from 10 to 46\% $\%^{9,12,15,17,19}$. Herpesviruses, HHV6, VZV, and a mixed infection by HHV6/EV, were detected in a lower propor$\operatorname{tion}^{20-22}$. In the present study in addition to enterovirus, positive samples for HSV (10\%), EBV (3\%) and HHV6 (3\%) were observed. Several studies have already shown mixed infection ${ }^{23}$. The involvement of herpesviruses as etiologic agents of meningitis or encephalitis has been 
extensively described in immunocompetent as well as immunossupressed patients ${ }^{23-25}$. Some authors report the difficulty to distinguish aseptic from bacterial meningitis due to the overlap of clinical symptoms and laboratory findings ${ }^{26,27}$. In this context, CSF examination is an essential part of the diagnostic analysis of patients with suspected CNS viral infection ${ }^{28}$. The classical pattern of viral meningitis is an increase of CSF WBCs, lymphomonocytary with normal glucose and elevated lactic acid. However, in the very acute stages of viral meningitis, chiefly in enteroviral meningitis, polymorphonuclear granulocytes may predominate and shifts to a mononuclear pleocytosis within 6 hours ${ }^{27,29}$. These patients also have benefic with the virus PCR analysis of CSF, as if the reaction is positive the patient is not submitted to antibiotic therapy and has prompt hospital discharge ${ }^{19}$. PCR has been proved to be a key method to detect viral infections of the $\mathrm{CNS}^{28}$. Molecular biology analysis offers advantages over cellular culture, because several days are taken for viral growth and identification using the latter method $^{30}$. The use of PCR based on the search of specific gene sequence 5'-UTR, a highly conserved region for different serotypes for enterovirus, demonstrates the advantage of this methodology since the results can be obtained in hours providing support in clinical practice and patient management, e.g. the use of antibiotics or the benefits of hospitalization ${ }^{31}$. Herpesviruses analysis by PCR has been found to present high sensitivity and sensibility and has definitely revolutionized virological diagnostic $^{28,31-33}$. Prior to PCR, the viral diagnosis of CNS infection was based on cellular culture of the CSF, brain biopsy or the demonstration of intrathecal antibody response, so that, in many instances the positive diagnostic was retrospective ${ }^{34}$. PCR has been largely used for CSF diagnosis with great advantages since it is possible to recover, amplify and detect low copies of the virus genome. In this study, DNA/RNA extraction was done as soon as possible to preserve and recover the viral genome from the CSF samples under PCR analysis. The material used for the procedure was DNA/RNAse free to minimize the inhibition factors for PCR analysis.

The high number of CSF samples negative for the viruses studied suggests other causes of lymphomonocytary meningitis, although less prevalent, could be associated. Other infectious agents such as Mycobacterium tuberculosis, Treponema pallidum, Cryptococcus neoformans, Lysteria monocytogenes, Brucella spp., Мycoplasma, neurocysticercosis, leptospirose or non infectious conditions including autoimmune diseases and carcinomatous meningitis must be considered ${ }^{29}$. Also other viruses not detected by PCR included adenovirus, HIV, measles, rubella and mumps.

Additionally, the implication of the many inhibiting factors in PCR results is well known. In CSF samples collected less than 3 days after the onset of neurological symptoms only $12 \%$ showed positive results. A higher positivity was observed on the fourth or fifth day ${ }^{34}$. In our study most of the CSF samples were collected on the second day (median 12hs) which could explain the high number of negative samples. Additionally, the elevated number of $R B C$ cells ( $\mathrm{p}=0.0071$ ), due to traumatic lumbar puncture, in the CSF's samples, as well as the presence of hemoglobin, probably had an inhibitory effect showing false negative results. We excluded from this analysis CSF samples with predomination of neutrophils, as the aim of this study was lymphomonocytary meningitis. This could have little impact in the number of positive PCR samples as the samples included in this study were collected with a mean of $12 \mathrm{hrs}$.

Finally, PCR analysis must include strict criteria in order to assure an accurate diagnosis. The standardization of the molecular technique confirms the validity of the PCR method for the rapid detection of RNA enterovirus and DNA herpesvirus in CSF. Enterovirus PCR takes eight hours and pan-herpes PCR takes four and a half hour. Further analysis of other agents and the standardization of biology molecular methodologies such as Real Time PCR are future proposition to improve the laboratorial diagnosis of viral meningitis in Brazil.

\section{REFERENCES}

1. Brown B, Oberste MS, Maher K, Pallansch MA. Complete genomic sequencing shows that polioviruses and members of human enterovirus species $\mathrm{c}$ are closely related in the noncapsid coding region. J Virology 2003;77:8973-8984.

2. Sawyer MH. Enterovirus Infections: diagnosis and treatment. Seminars in pediatrics infections diseases 2002;53:40-47.

3. Chadwick DR, Lever AML. The impact of new diagnostic methodologies in the management of meningitis in adults at a teaching hospital. Quart J Med 2000;95:663-670.

4. Brasil. Ministério da Saúde. Sistema de Informações de Saúde [updated 2007 Feb 01]. Available from: <hhtp:/tabnet.datasus.gov.br>

5. Kupila L, Vuorinen T, Vainionpää R, Hukknen V, Marttila RJ, Kotilainen P. Etiology of aseptic meningitis and encephalitis in an adult population. Neurology 2006;66:75-80.

6. Steiner I, Budka H, Chaudhuri A, et al. Viral encephalitis: a review of diagnostics methods and guidelines for management. Eur J Neurol 2005; 12:331-343.

7. Casas I, Powell L, Klapper P, Cleator G. New Method for the extraction of viral RNA and DNA from cerebrospinal fluid for use in the polymerase chain reaction assay. J Virol Meth 1995;53:25-36.

8. Casas I, Tenorio A, Echevarría JM, Klapper PE, Cleator GM. Detection of enteroviral RNA and specific DNA of herpesviruses by multiplex genome amplification. J Virol Meth 1997;66:39-50.

9. Casas I, Pozo F, Trallero G, Echevarría JM, Tenorio A. Viral diagnosis of neurological infection by RT multiplex PCR: a search for Entero and Herpesviruses in a prospective study. J Med Virol 1999;57:145-151.

10. Johnson G, Nelson S, Petric M, Tellier R. Comprehensive PCR-based assay for detection and species identification of human herpesviruses. J Clin Microbiol 2000;38:3274-3279.

11. Berlin L, Rorabaugh ML, Heldrich F, Roberts K, Doran T, Modlin J. Aseptic meningitis in infants <2 years of age: diagnosis and etiology. J Infect Dis 1993;168:888-892.

12. Archimbaud C, Chambon M, Bailly Jl, et al. Impact of rapid enterovirus molecular diagnosis on the management of infants, children, and adults with aseptic meningitis. J Med Virol 2009;81:42-48. 
13. Klowdenm M, Greenberg B. House fly and Drosophila cell cultures as hosts for human enteroviruses. J Med Entomol 1974:4:428-432.

14. Colimon R. Introduction to the virological diagnosis of the most frequent infections of the central nervous system. J Clin Virol 2002;25:51-53.

15. Shoja Z, Tabatabai H, Sarijloo M, Shahmahmoodi S, Azad TM, Nategh R. Detection of enteroviruses by reverse-transcriptase polymerase chain reaction in cell culture negative stool specimens of patients with acute flaccid paralysis. J Virol Meth 2007;142:95-97.

16. Santos GPI, Skraba I, Oliveira D, et al. Enterovirus meningitis in Brazil, 19982003. J Med Virol 2006;78:98-104.

17. Mendonza LP, Bronzoni R, Takayanagui OM, Aquino VH, Figueiredo LTM. Viral infections of the central nervous system in Brazil. J Infect 2006;54:6.

18. Lamarão LM, Gomes MLC, Ferreira LLA, et al. Pesquisa de enterovirus em casos de síndrome de meningite asséptica de Belém, PA. Rev Soc Bras Med Trop 2005;38:391-395.

19. King RL, Lorch AS, Cohen DM, Hodinka RL, Cohn KA, Shah S. Routine cerebrospinal fluid enterovirus polymerase chain reaction testing reduces hospitalization and antibiotic use for infants 90 days of age or younger. Pediatrics 2007;120:489-496.

20. Michos AG, Syriopoulou VP, Hadjichristodoulou C, et al. Aseptic meningitis in children: analysis of 506 cases. PLOS ONE 2007;8:674.

21. Brunel D, Lévéque N, Jacques J, Renois F, Motte J, Andréoletti L. Clinical and virological features of an aseptic meningitis outbreak in North-Eastern France, 2005. J Clin Virol 2008;42:225-228.

22. Takavoli NP, Wang H, Nattanmai S, Dupuis M, Fusco H, Hull R. Detection and typing of enteroviruses from CSF specimens from patients diagnosed with meningitis/encephalitis. J Clin Virol 2008;43:207-211.

23. Frantzidou F, Kamaria F, Dumaidi K, Skoura I, Antoniadis A, Papa A. Aseptic meningitis and encephalitis because of herpesviruses and enteroviruses in an immunocomptent adult population. Eur J Neurol 2008;15:995-997.
24. Gilden DH, Mahalingam R, Cohrs RJ, Tyler KL. Herpesvirus infections of the nervous system. Nat Clin Pract 2007;3:82-94.

25. Berger JK, Houff S. Neurological complications of herpes simplex virus type 2 infection. Clinical implications of basic neuroscience research 2008;63: 396-399.

26. Almeida SM, Faria FL, Fontes KG, et al. Quantitation of cerebrospinal fluid lactic acid in infectious and non-infectious neurological diseases. Clin Chem Lab Med 2009;47:755-761.

27. Shah SS, Hodinka RL, Turnquist JL, Elliott MR, Coffin SE. Cerebrospinal fluid mononuclear cell predominance is not related to symptom duration in children with enteroviral meningitis. J Pediatrics 2006;148:118-121.

28. Cinque P, Bossolasco S, Lundkvist A. Molecular analysis of cerebrospinal fluid in viral diseases of the central nervous system. J Clin Virol 2003;26: $1-28$.

29. Almeida S M, Nogueira M B, Raboni S M, Vidal L R R. Laboratorial diagnosis of lymphocytic meningitis. Brazilian J Infect Dis 2007;11:478-484.

30. Ramers C, Billman G, Hartin M, Ho S, Sawyer M. Impact of a diagnostic cerebrospinal fluid enterovirus polymerase chain reaction test on patient management. J Amer Med Associat 2000;283:2680-2685.

31. DeBiasi RL, Tyler KL. Molecular methods for diagnosis of viral encephalitis. Clin Microbiol Rev 2004;17:903-925

32. Chesky M, Scalco R, Failace L, Read S, Jobim LF. Polimerase chain reaction for the laboratory diagnosis of aseptic meningitis and encephalitis. Arq Neuropsiquiatr 2000;58:836-842.

33. Minjolle S, Arvieux C, Gautier AL, et al. Detection of herpesvirus genomes by polymerase chain reaction in cerebrospinal fluid and clinical findings. J Clin Virol 2002; 25(Suppl):S59-S70.

34. Davies NWS, Brown LJ, Gonde J, et al. Factors influencing PCR detection of viruses in cerebrospinal fluid of patients with suspected CNS infections. J Neurol Neurosurg Psychiatry 2005;76:82-87. 